\title{
The Status Quo \& Countermeasures of the Young Students Holiday Eco-tourism
}

\author{
Shulong HU \\ Nanyang Institute of Technology, Nanyang, Henan 473000, China
}

\begin{abstract}
Holiday travel is a new phenomenon in the scope of consumption in our country. Young students eco-tourism is an important part of the holiday travel, as a special consumer groups, they have their own characteristics. This paper analyzes the current situation and characteristics of young students holiday eco-tourism, and proposed the corresponding countermeasures.
\end{abstract}

KEYWORD: Holiday Travel; Status Quo; Countermeasures

Holiday travelling is an economic activity that occurred when millions of households can consume a variety of tourism products with their whole family or the majority of family members during the best festive atmosphere and climate in a year when our country extended "the October 1st Holiday", shortened "the May 1st Holiday", added the Tomb Sweeping Day holiday, the Dragon Boat Festival holiday, the Mid-Autumn Festival holiday, the Double Ninth Festival holiday and other statutory leisure times. Generally believed that the holiday travel has the broad and narrow senses. Holiday travel in the broad sense refers to people's tourism activities during a variety of festivals, anniversaries, holidays and summer and winter vacations [1]. While in the narrow sense, it refers to the tourism activities during the Spring Festival, "the October 1st Holiday" (also known as the Golden Week holidays) and the other long holidays of our citizens. Ecotourism is the function in three bodies of the tourists, tourism development managers and the government. It is based on the premises that the ecological environment should be protected, and by providing tourists with a good education of the tourism environment and ecological knowledge, the tourists demand for ecotype consumption was met and their behavior is restrained [2]. Young students Ecotourism is an important part of the holiday tourism, it plays a very important role in the tourism industry.

\section{THE STATUS AND CHARACTERISTICS OF YOUNG STUDENTS HOLIDAY ECOTOURISM ANALYSIS}

\subsection{The current situation of young student's holiday ecotourism analysis}

After joining the WTO, the connection between the development of China's tourism and the international tourism industry was enhanced day by day. The importance of the position and role of tourism in the national economy is increasing.

And how to expand the tourism market and to foster tourism highlights have become the attention of many people in this industry. Because of its rapid pace of development and distinctive vitality, the young student's holiday eco-tourism has becoming a quite active and potential market. The main reason for the rapid development of the youth eco-tourism market is the impact of subjective and objective environment. On the one hand owning to a complex tourist business environment and personal social environment, the youths are faced with an increasingly popular tourism consumer behavior and the huge tourism promotional campaign, also coupled with its strong desire for external things, under the combined effects of these various factors, they have a strong interest in tourism and pose a strong motivation to travel; On the other hand, with the rapid development of the national economy, Residents have a substantial increase in disposable income, In 2001, China's urban residents disposable income per capita reached to 6,650 Yuan, equivalent to $\$ 750-800$, In 2011, China's urban residents disposable income per capita reached to $21,810 y u a n$ [3], equivalent to \$3294-3461. In the past ten years, the disposable income of urban 
residents per capita increased by nearly $228 \%$. According to experts' analysis, this income level is the rapid expansion of tourism consumption stage, meanwhile, at present; most of the urban households have only one child. These two reasons integrated lead to more and more parents will be required to support the cost of investment in the growth of children as the main household spending plans, hoping their children can broaden their horizons, relax and increase their knowledge when travelling. Therefore, young students eco-tourism become increasingly popular, In particular, the infirmary tour with a main purpose of increasing knowledge and exploring wonders with a purpose of seeking pleasure have becoming a favor of the vast number of the youth.

\subsection{Young student's holiday Eco-tourism characteristics analysis}

Young students as a special consumer groups, unlike other travelers in the age structure, physiology, tourism psychology, their tourism activities have their own characteristics.

\subsubsection{Large amount of outside tourism activities, giving priority to the individual travel way}

In 2011, for example, national domestic tourists reached 2.64 billion, If day-trippers are excluded and take the number of overnight visitors as $1 / 4$ of this data as an estimation, it is about 700 million people, the national travel rate is about 50\% [4]. Youth travel rate also increased year by year, this suggests that young people eco-tourism have a huge market, Potential would be further developed. Because their pursuit of freedom and unregulated nature, young people mostly choose to travel more in the way of individual travels, group travel as supplement. In the process of individual travels, mostly their numbers were about 2-7 people, Fewer number of trips alone, and the scope of activities more in the close area.

\subsubsection{Lacking self-care ability, Basic consumption- based consumer characteristics}

Currently, in our country, especially in urban households, a large proportion of one child, They tend to be loved by parents excessively, but lacking disciplines. Making them much in life and psychological dependence on their parents, Poor ability to live independently, many parents hope that through eco-tourism, children's self-reliance, selfcare, and hard-working spirit would be cultivated. Their physique can be exercised, so as to facilitate their healthy growth. On the other hand, young people are in the learning stage of knowledge, without source of income, their tuition, living expenses and travel expenses, mostly coming from parents, even some young people rely on their vacation time to get some income, but relatively speaking, only be regarded as inadequate. This situation determines the consumption characteristics of young eco-tourism to be basic consumer-oriented, Costs more for food, housing, sightseeing, entertainment, shopping and special travel does not cost much.

\subsubsection{Long vacation, easy to be dispersed}

Compared with most other young students tourists, the biggest advantage are that a longer vacation. Because for most tourists, they only have off days and public holidays, the above mentioned holidays in a narrower sense. While the young students have around three months of summer and winter vacations than most people. Longer holidays, not only conducive to young people in ecotourism holiday travel time and travel arrangements flexible routes, Golden Week tourism has slowed too, concentrated to transport, reception areas, accommodation, catering and other departments of the enormous pressure.

\section{SECOND, THE YOUNG STUDENTS ECOTOURISM HOLIDAY PROBLEMS}

Although young student's holiday eco-tourism has become a new bright spot, but because of the many features of its own, many tourist sites are not really supporting the construction or better mechanism for young eco-tourism travel features, to promote youth holiday eco-tourism vital development. Currently youth ecotourism holidays still have many problems.

\subsection{Eco-tourism market is unfocused}

Although many travel agents have been involved in young students holiday co-tourism market, they did not take into account the characteristics of their own youth travelers, Many products come into the market hastily, he low end of the tourist products being packaged and send bake to the market again. Some was even just a simple repetition of the content of the classroom, with form of old-fashioned, able to effectively meet the needs of young students ecotourism products are few. From seeing the entire student's eco-tourism market, products forms are over tedious, lacking features and characteristics.

\subsection{The lack of eco-tourism related policies}

Cost is the biggest factor affecting youth travel, but most of the tourist attractions as the main purpose of profit, Products designed for young students is much higher than the price level of consumption, Lack of incentives related to the student, causing many young people tourists look "tour" deterred. In addition, the state of young people travel there is no 
clear correlation introduced preferential policies, Youth travel in tickets, accommodation and tickets are still many other aspects of distress.

\subsection{Security issues are not paying enough attention}

Security requirement is one of the most basic needs of the people. Young students in tourism, especially in the holiday Eco-tourism should focus on security issues. In recent years, holiday Eco-tourism become increasingly popular, because tourists too concentrated, and various scenic spots are often overcrowded Travel accident abound. This gives people travelling overshadowed. As youth awareness is poor, safety factor is more important, it require the relevant departments to strengthen management, to ensure the safety of youth Eco-tourism.

\section{THE COUNTERMEASURES FOR DEVELOPING THE YOUNG STUDENTS HOLIDAY ECO-TOURISM}

Tourism should be targeting young people with its own characteristics of Eco-tourism and existing problems, this the youth holiday Eco-tourism as a new economic growth point, continuously develop of youth Eco-tourism, refine countermeasure of the young students Eco-tourism.

\subsection{To improve the cultural quality of Eco-tourism products, pay attention to young students tourists participation, satisfy desire to obtain knowledge, novelty, and strange}

Holiday Eco-tourism is a dynamic form of education must have a function of education especially for infirmary tourism, Should pay more attention to reflect their educational, cultural and scientific characteristics. Young students at different ages, because of physical, mental and different knowledge structure, the different needs of the tourism products are different. Therefore, the development of Ecotourism products must not "equal", we should first analyze young students Eco-tourism market, Then according to their respective characteristics to develop marketable products. For about 7-15 years old students participating in tourism activities, tourism, various forms of summer camps, visiting Museums, cultural centers, red base, tourism and other acclaimed language learning are much welcomed, Among them, tech camps especially attracted students attention. For 16-18 year-old high school students, need to play a prestigious university in the "Halo" effect, organization should focus on the prestigious university infirmary tours, the "Celebrity Tour" and the science tour. For the purposes of 19-24-year-old university student, due to financial constraints, students tend to gain the most from the Eco-tourism and the city has become the first choice for students travelling. Then, to develop the characteristics of urban Eco-tourism products, to increase its cultural connotations, to develop appropriate national customs tour. And based on young people exploring everything has a psychological, Science and technology development department study tours organized jointly, the new attraction of students organized their own reconnaissance trips together and find the odd adventure travel. In addition, exploiting sports Ecotourism products, at the same time, taking diving, parachuting, climbing, cycling, etc. into the development system, intensify the development of sports products. In short, a high-grade, high-quality Eco-tourism product is the main factor in students' growing Eco-tourism market.

\subsection{The development of supporting policies, Strengthening the relevant facilities and student financial ability to adapt, encourage young students to travel}

"Backpack walks the world" is the dream of many young students leave, because enough time, but the lack of economic conditions, they are mostly used Walks way. However, the ensuing circuit design, transportation, accommodation costs and other issues people look "tour" sigh. Therefore, to better develop good overall student tourist market, The State shall implement appropriate policies, Encourage young students to ecotourism. In this regard, Some foreign countries do quite well, Such as the International Student Association headquarters in Copenhagen, Denmark in the early 1990s, For young students travel discount cards sold each year amounted to 1.5 million, Student cardholders enjoy airfare, accommodations, tours and other concessions; These tourism powers the United States, Japan, Germany, also provided to students in all aspects of tourism incentives Such as hotels, etc. with college students. Our country can learn from their advanced experience, Take government guidance, enterprise investment in the form of Charge a lower fee in student travel tickets, accommodation, sightseeing attractions tickets. But can also build youth hostels, family hotels, Established tourist camp, tents and other lowerpriced accommodations.

\subsection{Enhancing Students travel safety education and safety management, for the creation of a safe and comfortable environment}

US market experts who will travel related Barry.J.Babbin customer satisfaction or dissatisfaction process models included in the field of tourism research students, in this model. He security (salty) as customer satisfaction or 
dissatisfaction (CS/D) an important factor, this suggests an important role in the safety of the tourism industry [5. Generally speaking, Tourism is tourism safety of life, Play an important role in tourism development. It is not only the protection of eco-tourism activities, Also a prerequisite for the development of eco-tourism. Only under conditions of safety of tourists in, to really relax, into the purpose and nature. Relatively speaking, young people still in the immature stage, Lack of selfprotection awareness, Poor self-defense capability, once the problem occurs, often lead to a series of social problems. At present, although China has enacted such as "tourism safety management Interim Measures" Major tourism safety incident reporting system pilot scheme" and a number of local tourism safety rules and regulations, but most only stay at the policy level, No real fine place to implement. Ecotourism in our country, there is still security risks. To this end, in addition to foreign laws and regulations should continue to strengthen the building, It should also establish appropriate ecotourism security agencies and security early warning systems; Improve the eco-travel insurance; Establishing health stations and food hygiene management agencies in various attractions: Strengthening ecological tourism safety education. Improve passenger safety awareness Such education is not only for students, But also for the majority of consumer groups and other tourist services, providing a safe and comfortable environment for young students.

\subsection{Strengthen the city suburbs and other eco- tourism attractions building, open weekend tours, ecological protection awareness training for young students}

Weekend leisure travel market has its own characteristics, Tourists mostly basic consumer spending, and other additional costs much. Very suitable for young student's eco-tourism, in addition, when considering traveling transport, Range of traffic conditions and tourist activities and more in between 100 to $150 \mathrm{~km}$, therefore, it is very adapt to the needs of youth eco-tourism. Tourism sector should focus on the outskirts of the natural attractions of the building, Development of new, strange, exciting, challenging, personal involvement and strong project Focus on play parks, forests, mountains and the role of agriculture in rural and suburban ecology, Open forest paths, eco-tourism, agriculture tour, countryside tours, etc. Allow young students to observe the flora and fauna living habits, Production plant and animal specimens, "Eat rice farmers, live in farm homes, Do farmers live, to see the farm scene, thus, not only learned to feel the charm of nature knowledge, but also cultivate students' awareness of ecological protection, and promote the sustainable development of eco-tourism.

\section{CONCLUSION}

Youth Holiday ecotourism market opened, Not only meet the physiological and psychological needs of adolescents, Conducive to the healthy growth of young people, Compensate for the lack of home schooling, Holiday travel can promote China's economic development, Improve the types and levels of tourism products, Away from the traditional model of a single tourism product, Largely developed country trips and study tours ecology. So that young students the wonders of nature at the same time feel, Stimulate awareness of ecological protection, So as to achieve the economic, environmental and social unity. Students of ecotourism in their own long holiday, the number of people, potential characteristics, attracted the attention of more and more people in the industry. Only by improving product quality, Develop incentives Increased marketing efforts, Provide convenient, safe and comfortable environment for students tourism tourists. In order to ensure the smooth development of eco-tourism market of young students. The near future, Holiday ecotourism young students will become a new bright spot in another tourism.

\section{REFERENCES}

[1] Qian Wenfang. Our Holiday Travel Problems and Countermeasures. 2006 Hunan College of Finance and Economics (8): 94-95.

[2] Zhou Xiaoyuan. Ecotourism connotation Re - discussion with Mr. Guo Shu questionable. Tourism Tribune. 2002(1).

[3] Jiang YanXin, Shen Wei Qing. Bureau: Last year, per capita income of urban residents 23,979 yuan. Beijing News 2012-01-21.

[4] The Road We Must Follow domestic tourism statistics should go to the water. China Youth Daily. 2012-02-10. (11th Edition)

[5] Cai and Jane on the students' travel behavior and consumer choice model. Beijing International Studies University. 2002 (1): 29-32. 